\title{
INTEGRITAS SEBAGAI PEMODERASI PENGARUH TEKANAN ANGGARAN WAKTU, KOMPLEKSITAS TUGAS, DAN PENGALAMAN KERJA PADA KUALITAS AUDIT (Studi Empiris pada Inspektorat Kabupaten Tegal Provinsi Jawa Tengah)
}

\author{
Dyah Ayu Pangastuti \\ Inspektorat Kab. Tegal, aqilapangastuti@gmail.com
}

\begin{abstract}
ABSTRAK
Kegiatan audit oleh auditor pemerintah belum mencerminkan perencanaan yang cermat, pelaksanaan yang tepat, pelaporan yang andal, dan perbaikan kualitas audit yang berkelanjutan. Faktor-faktor yang dapat mempengaruhi kualitas audit, antara lain: tekanan anggaran waktu, kompleksitas tugas, pengalaman kerja, dan integritas. Tujuan penelitian ini memperoleh bukti empiris mengenai integritas sebagai pemoderasi pengaruh tekanan anggaran waktu, kompleksitas tugas, dan pengalaman kerja pada kualitas audit di Inspektorat Kabupaten Tegal. Populasi dari penelitian ini adalah seluruh auditor Inspektorat Kabupaten Tegal yang berjumlah 25 orang, sampel penelitian adalah menggunakan teknik sampling jenuh yaitu pada semua populasi yang berjumlah 25 responden. Pengumpulan data menggunakan kuesioner, teknik analisis data menggunakan regresi linier berganda. Hasil Penelitian menunjukkan bahwa integritas tidak terbukti memoderasi pengaruh tekanan anggaran waktu dan pengalaman kerja pada kualitas audit, akan tetapi integritas terbukti memoderasi pengaruh kompleksitas tugas pada kualitas audit di Inspektorat Kabupaten Tegal. Saran bagi pihak Inspektorat Kabupaten Tegal berusaha melakukan pendidikan dan pelatihan pada auditor, audit sebaiknya dilakukan oleh auditor yang sudah cukup berpengalaman, atau dapat juga diberikan pada auditor yang belum cukup memiliki pengalaman kerja tetapi harus didampingi oleh auditor yang sudah cukup berpengalaman.
\end{abstract}

Kata Kunci: Kualitas audit, tekanan anggaran waktu, kompleksitas tugas, pengalaman kerja, integritas

\section{Pendahuluan}

Selama rentang waktu dua dekade terakhir, lingkungan organisasional sektor publik telah mengalami banyak perubahan seiring reformasi untuk menuju tata kelola yang baik (good governance) (Prabowo dkk., 2013). Untuk itu, audit pada sektor publik diperlukan guna memberikan jaminan terhadap peningkatan akuntabilitas dan transparansi bagi tata kelola pemerintahan. Hasil audit akan memberikan umpan balik bagi semua pihak yang terkait dengan entitas sektor publik, baik internal maupun eksternal (Rai, 2008).

Sebagaimana disebutkan dalam Dalam Peraturan Bupati Tegal Nomor 70 Tahun 2016 tentang Kedudukan, Susunan
Organisasi, Tugas Dan Fungsi Serta Tata Kerja Inspektorat Kabupaten Tegal Penjabaran Tugas Pokok Dan Fungsi, Serta Tata Kerja Inspektur, Sekretaris, Inspektur Pembantu Wilayah, Kepala Sub Bagian Dan Kelompok Jabatan Fungsional di Lingkungan Pemerintah Kabupaten Tegal Pasal 2 ayat 1 , ayat 2 , dan ayat 3 , sebagai unsur pengawas penyelenggaraan Pemerintah Daerah yang bertanggungjawab kepada Bupati, Inspektorat Kabupaten Tegal memiliki tugas dan kewajiban membantu Bupati dalam membina dan mengawasi pelaksanaan urusan Pemerintahan yang menjadi kewenangan Daerah dan Tugas Pembantuan oleh Perangkat Daerah. Inspektorat dalam melaksanakan tugasnya 
menyelenggarakan fungsi antara lain perumusan kebijakan teknis bidang pengawasan dan fasilitasi pengawasan, pelaksanaan pengawasan internal terhadap kinerja dan keuangan melalui audit, reviu, evaluasi, pemantuan, dan kegiatan

pengawasan lainnya, pelaksanaan pengawasan untuk tujuan tertentu atas penugasan Bupati, dan sampai pada tahapan penyusunan dan tindak lanjut Laporan Hasil Pengawasan.

Sebagai unsur pengawas penyelenggaraan pemerintahan daerah atau sebagai Aparat Pengawasan Intern Pemerintah (APIP), Inspektorat Kabupaten Tegal membantu Bupati dalam hal bertanggung jawab atas efektivitas penyelenggaraan Sistem Pengendalian Internal di lingkungannya sehingga menuntut peran APIP agar menghasilkan audit yang berkualitas guna : (a) memberikan keyakinan yang memadai atas ketaatan, kehematan, efisiensi, dan

efektivitas pencapaian tujuan penyelenggaraan tugas dan fungsi Instansi Pemerintah; (b) memberikan peringatan dini, dan meningkatkan efektivitas manajemen risiko dalam penyelenggaraan tugas dan fungsi Instansi Pemerintah; serta (c) memelihara dan meningkatkan kualitas tata kelola penyelenggaraan tugas dan fungsi Instansi Pemerintah (Peraturan Pemerintah 60, 2008).

Banyaknya temuan hasil pemeriksaan yang berdampak pada finansial dari temuan hasil pemeriksaan BPK selama Tahun 2012 sampai dengan Tahun 2016. Sedangkan gambar 1.2 menunjukkan nilai rekomendasi hasil pemeriksaan dari Tahun 2012 sampai dengan tahun 2016. BPK RI Perwakilan Provinsi Jawa Tengah menilai bahwa kegiatan audit oleh auditor pemerintah belum mencerminkan perencanaan yang cermat, pelaksanaan yang tepat, pelaporan yang andal, dan perbaikan kualitas audit yang berkelanjutan (BPK, 2014).

Government Accountability Office (GAO) mendefinisikan kualitas audit sebagai ketaatan pada standar profesi dan perikatan kontrak selama audit berlangsung
(Lowenshon et al., 2005). Pengakuan kualitas audit oleh lingkungan organisasi bergantung pada penegasan dan legitimasi hasil audit dan nilai yang diperoleh dari metodologi audit yang dilakukan (Herrbach, 2001). Standar, kode etik, dan petunjuk teknis audit merupakan prasyarat dasar yang diperlukan sebagai jaminan kualitas (quality assurance) di dalam proses audit (Karapetrovic dan Willborn, 2010). Komite Standar Audit Internal Pemerintah menyebutkan bahwa prasyarat dasar tersebut menjadi ukuran mutu mandat penugasan untuk mewujudkan hasil audit intern yang berkualitas. Kualitas audit juga bergantung pada kinerja tim audit (Herrbach, 2001). Pada dasarnya, proses audit merupakan usaha bersama setiap jenjang penugasan audit untuk memastikan kualitas pada setiap tahapan dalam proses audit tersebut. Dalam hal ini, telaah berjenjang merupakan bagian penting dari mekanisme pengendalian kualitas audit (Tan and Jamal, 2001). Telaah berjenjang dilakukan untuk memastikan kesesuaian kegiatan audit dengan standar, dan mengevaluasi apakah auditor telah menerapkan kode etik.

Beberapa penelitian telah dilakukan untuk menguji faktor-faktor yang dapat mempengaruhi kualitas audit, antara lain: tekanan anggaran waktu, kompleksitas tugas, pengalaman kerja, dan integritas. Tekanan anggaran waktu merupakan faktor utama yang dapat mengurangi kualitas audit dan kinerja auditor (Willet dan Page, 1996). Sososutikno (2003) mendefinisikan tekanan anggaran waktu sebagai keadaan yang menunjukkan bahwa auditor dituntut untuk melakukan efisiensi terhadap anggaran waktu yang telah disusun, atau terdapat pembatasan waktu dan anggaran yang sangat ketat dan kaku. Auditor dengan kondisi yang tertekan oleh anggaran waktu audit yang ketat, akan memberikan respon dengan dua cara, yaitu: fungsional dan disfungsional (DeZoort and Lord, 1997 dalam McNamara dan Liyanarachchi, 2008). Beberapa penelitian terdahulu menunjukkan bahwa

perilaku disfungsional mengancam terjadinya penurunan kualitas audit (Otley 
dan Pierce, 1996; Herrbach, 2001; Coram et al., 2003; Pierce dan Sweeney, 2004).

Selain tekanan anggaran waktu, kompleksitas tugas audit berperan mempengaruhi kualitas audit. Kompleksitas tugas didefinisikan sebagai tugas yang kompleks, terdiri atas bagian-bagian yang banyak, berbeda-beda, dan saling terkait satu sama lain (Engko dan Gudono, 2007). Penelitian Bonner (1994) menemukan bahwa peningkatan kompleksitas tugas berhubungan dengan penurunan kualitas judgment (pertimbangan) auditor dan peningkatan bias pada judgment. Temuan tersebut didukung oleh hasil penelitian lainnya yang menunjukkan bahwa kompleksitas tugas memberikan arah negatif pada kualitas audit (Prasita dan Adi, 2007). Namun, hasil penelitian Praditaningrum dan Januarti (2012), Jamilah dkk.(2007), dan Zulaikha (2007) menunjukkan bahwa kompleksitas tugas tidak berpengaruh secara signifikan pada kinerja auditor dalam pembuatan dan keakuratan judgment.

Bonner dan Lewis (1990) menyatakan bahwa peningkatan pengetahuan yang muncul dari pengalaman khusus, sama bagusnya dengan yang didapat dari penambahan pelatihan formal dalam rangka memenuhi persyaratan sebagai seorang profesional. Auditor yang berpengalaman lebih jelas merinci masalah yang dihadapi jika dibandingkan dengan auditor yang kurang berpengalaman, sehingga dapat meningkatkan kualitas audit (Mabruri dan Winarna, 2010). Beberapa penelitian menunjukkan bahwa pengalaman kerja berpengaruh secara signifikan terhadap kualitas hasil audit (Sukriah dkk., 2009; Mabruri dan Winarna, 2010; Wiratama dan Budiartha, 2015). Namun, hasil penelitian Singgih dan Bawono (2010), serta Nugraheni (2009) menemukan bahwa pengalaman auditor pemerintah tidak terbukti berpengaruh dalam meningkatkan kualitas audit.

Keandalan hasil pengaruh tekanan anggaran waktu, kompleksitas tugas, dan pengalaman kerja pada kualitas audit yang berbeda-beda, menimbulkan dugaan adanya faktor kontekstual lainnya yang mungkin akan berinteraksi dalam mempengaruhi situasi tersebut. Dalam hal ini, fenomena kualitas audit tidak serta merta hanya dipengaruhi oleh faktor-faktor seperti tekanan anggaran waktu, kompleksitas tugas, dan pengalaman kerja. Integritas seorang auditor diduga dapat memperlemah dan memperkuat pengaruh tekanan anggaran waktu, kompleksitas tugas, dan pengalaman kerja pada kualitas audit.

Integritas merujuk pada segala hal yang membuat seseorang bisa dipercaya (Agoes dan Ardana, 2009). Ketidak percayaan masyarakat terhadap satu atau beberapa auditor dapat merendahkan martabat profesi secara keseluruhan sehingga dapat merugikan auditor lainnya (Ulum, 2009). Untuk itu, integritas auditor haruslah yang terpenting, sebagai upaya untuk mematuhi aturan independensi dan menghindari konflik kepentingan yang dilarang pada saat memberikan jasa audit (DeZoort, 2012). Penelitian Srivastava (2002) menunjukkan bahwa integritas merupakan variabel kunci untuk meminimalkan risiko independensi yang mengancam tingkat kepercayaan pada kemampuan auditor untuk menghasilkan keputusan audit yang tidak bias. Dengan demikian, integritas yang tinggi akan meningkatkan kualitas audit (Pusdiklatwas BPKP, 2008). Hal ini didukung oleh hasil beberapa penelitian terdahulu (Mabruri dan Winarna, 2010; Parasayu dan Rohman, 2014; Cahyono dkk., 2015) yang membuktikan bahwa integritas berpengaruh secara signifikan terhadap kualitas audit.

Penelitian ini bertujuan untuk memperoleh bukti empiris mengenai integritas sebagai pemoderasi pengaruh tekanan anggaran waktu, kompleksitas tugas, dan pengalaman kerja pada kualitas audit di Inspektorat Kabupaten Tegal.

\section{Metode Penelitian}

Jenis penelitian penjelasan (explanatory research) karena bermaksud menjelaskan hubungan kausal antara variabel-variabel melalui pengujian hipotesis. Sumber data 
yang digunakan dalam penelitian ini meliputi data primer, yaitu data yang diperoleh dari responden melalui kuesioner yang telah dibuat sesuai dengan indikator penelitian dan juga berdasarka data sekunder. Populasi dari penelitian ini adalah seluruh seluruh auditor Inspektorat Kabupaten Tegal. Teknik total sampling yaitu 25 orang.

Metode pengumpulan data yang digunakan dalam penelitian ini adalah menggunakan kuisioner yang disampaikan kepada Inspektorat Kabupaten Tegal. menggunakan instrument penelitian berupa kuesioner atau angket yang disebarkan kepada responden. Skala yang digunakan untuk mengukur indikator-indikator variabel dalam kuisioner adalah Skala Likert. Analisis data menggunakan regresi linier berganda dengan variabel moderasi setelah terlebih dahulu dilakukan uji asumsi klasik dan uji kelayakan model.

\section{Hasil dan Pembahasan a. \\ Uji Validitas Validitas}

Uji validitas menggunakan koefisien korelasi Product Momen Pearson. Butir kuesioner dinyatakan sahih atau valid, jika Rhitung > Rtabel, uji validitas dilakukan pada 23 responden di luar responden penelitian, sehingga didapatkan Rhitung adalah 0,413. Hasil uji validitas yang dilakukan dengan menggunakan program SPSS 17, maka kuesioner tentang tekanan anggaran waktu ( $\left.\mathrm{X}_{1}\right)$, kompleksitas tugas $\left(\mathrm{X}_{2}\right)$, pengalaman kerja $\left(\mathrm{X}_{3}\right)$, integritas (X4) dan kualitas audit (Y) dinyatakan valid karena Rhitung masing-masing butir kuesioner diatas nilai $\mathrm{R}$ Tabel, 0,413.

\section{b. Reliabilitas}

Tabel 1 Reliabilitas

\begin{tabular}{|l|l|}
\hline Variabel & Alpha \\
\hline Tekanan Anggaran Waktu & 0,938 \\
Kompleksitas Tugas & 0,805 \\
Pengalaman Kerja & 0,757 \\
Integritas & 0,963 \\
Kualitas Audit & 0,916 \\
\hline
\end{tabular}

Dari kelima variabel nilai $\mathrm{r}$ alpha yang dihasilkan bernilai positif dan lebih besar dari 0,06. Hasil keseluruhan instrumen penelitian ini handal.

\section{c. Pengujian Persyaratan Analisis}

1) Uji Normalitas

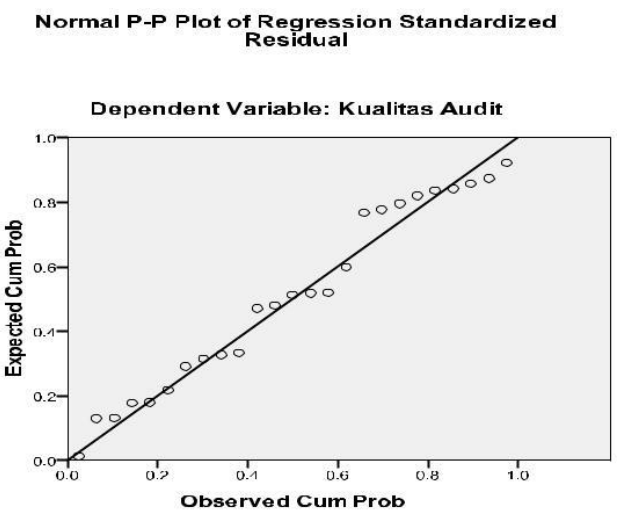

Berdasarkan gambar di atas dapat diketahui bahwa penyebaran data (titik) pada Normal P-Plot of Regression Standardized dari variabel terikat menyebar di sekitar garis diagonal, maka model regresi memenuhi asumsi normalitas.

2) Uji Multikoliniaritas

Tabel 2 Hasil Uji Multikolinier

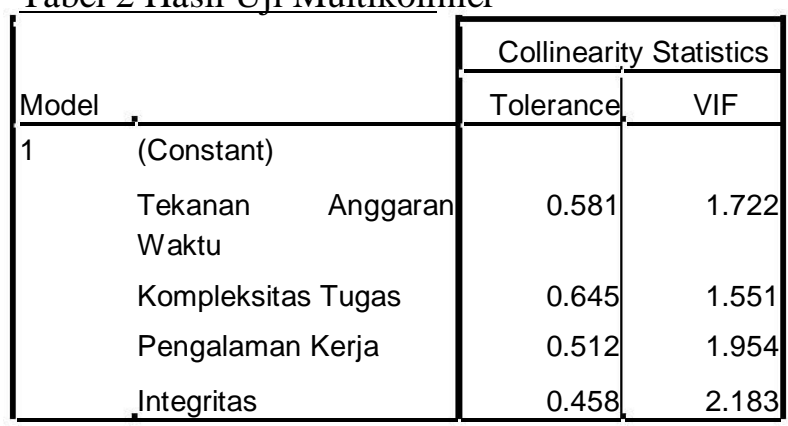

Hasil uji multikolinearitas pada pada tabel di atas diketahui bahwa hasil tolerance pada masing-masing variabel lebih besar dari 0,1 , sedangkan nilai Varians Inflation Factor (VIF) lebih kecil dari 10. Sehingga model regresi dalam penelitian ini tidak ada masalah multikolinearitas. 
3) Uji Heteroskedastisitas

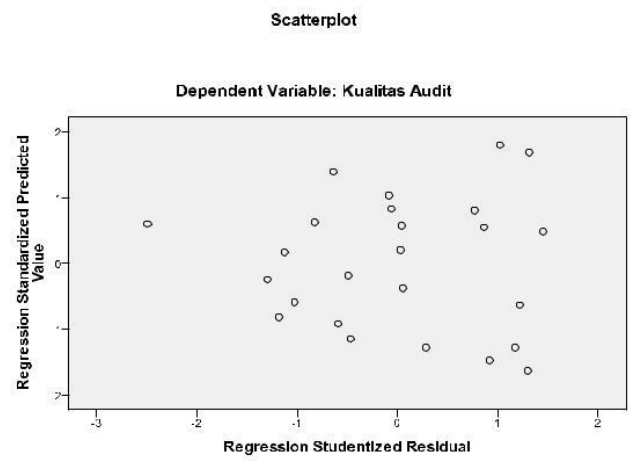

Gambar di atas tidak menunjukkan adanya pola tertentu yang berarti tidak terjadi heterokodesitas dalam model regresi.

4) Uji Autokorelasi

Berdasarkan hasil penelitian menunjukkan bahwa nilai DW sebesar 1,932 , terletak diantara dU $(1,7670)$ dan 4-dU (2,233), sehingga tidak ada autokorelasi

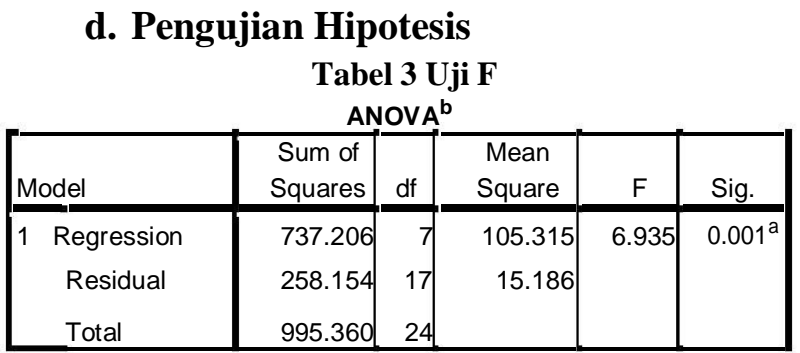

a. Predictors: (Constant), X3.X4, Tekanan Anggaran Waktu, Kompleksitas Tugas, Integritas, Pengalaman Kerja , X2.X4, X1.X4

b. Dependent Variable: Kualitas Audit

Uji F menghasilkan Fhitung sebesar 6,935 dengan signifikasi sebesar 0,001 atau kurang dari 0,05. Dengan demikian dapat disimpulkan bahwa model mampu memprediksi nilai observasinya, atau model dapat diterima karena cocok dengan data observasinya.

\section{Tabel 4 Koefisien Determinasi} Model Summary

\begin{tabular}{|l|c|r|r|r|}
\hline Model & $\mathrm{R}$ & $\mathrm{R}$ Square & $\begin{array}{c}\text { Adjusted R } \\
\text { Square }\end{array}$ & $\begin{array}{c}\text { Std. Error of the } \\
\text { Estimate }\end{array}$ \\
\hline 1 & $.861^{\mathrm{a}}$ & .741 & .634 & 3.89686 \\
\hline
\end{tabular}

a. Predictors: (Constant), X3.X4, Tekanan Anggaran Waktu, Kompleksitas Tugas, Integritas, Pengalaman Kerja , X2.X4, X1.X4
Dari tabel 5.19 diketahui bahwa nilai Adjusted $R$ Square adalah 0.634 yang berarti bahwa 63,4 persen variasi variabel terikat kualitas audit dapat dijelaskan oleh variasi variabel bebas tekanan anggaran waktu, kompleksitas tugas, pengalaman kerja yang dimoderasi oleh variabel integritas, sedangkan sisanya sebesar 36,6 persen dijelaskan oleh variabel-variabel lain di luar model penelitian.

Tabel 5. Uji t

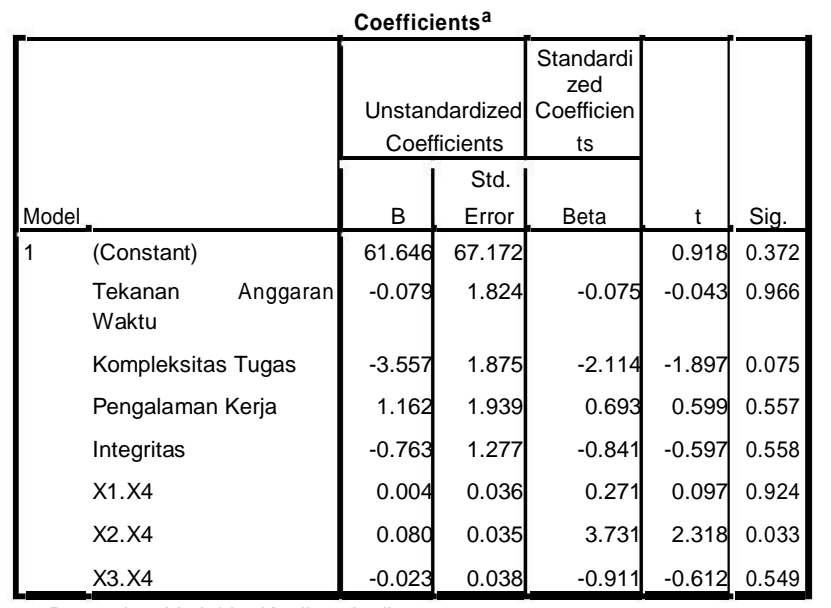

a. Dependent Variable: Kualitas Audit

Dari hasil perhitungan diperoleh hasil sebagai berikut:

Uji hipotesisis integritas memperkuat pengaruh tekanan anggaran waktu pada kualitas audit

Interaksi tekanan anggaran waktu dengan integritas (X1X4) menunjukkan thitung adalah sebesar 0,097 dengan nilai signifikansi sebesar 0,924. Nilai signifikansi ini memiliki arti bahwa integritas auditor tidak mampu memoderasi tekanan anggaran waktu terhadap kualitas audit. Karena nilai standardized coefficient beta 0,271 dan nilai signifikan $(0,924)>0,05$. Hal ini berarti integritas auditor tidak mampu memoderasi tekanan anggaran waktu terhadap kualitas audit sehingga hipotesis pertama ditolak.

\section{Uji hipotesisis integritas memperkuat pengaruh kompleksitas tugas pada kualitas audit}

Interaksi kompleksitas tugas dengan integritas (X2.X4) menunjukkan t-hitung adalah sebesar 2,318 dengan nilai signifikansi sebesar 0,033 . Nilai signifikansi ini memiliki arti bahwa 
integritas auditor mampu memoderasi kompleksitas tugas terhadap kualitas audit. Karena nilai standardized coefficient beta 3,731 dan nilai signifikan $(0,033)<0,05$. Hal ini berarti integritas auditor mampu memoderasi kompleksitas tugas terhadap kualitas audit sehingga hipotesis kedua ditolak.

\section{Uji hipotesisis integritas memperkuat pengaruh pengalaman kerja pada kualitas audit}

Interaksi pengalaman kerja dengan integritas (X3.X4) menunjukkan t-hitung adalah sebesar 0,612 dengan nilai signifikansi sebesar 0,549. Nilai signifikansi ini memiliki arti bahwa integritas auditor tidak mampu memoderasi pengalaman kerja terhadap kualitas audit. Karena nilai standardized coefficient beta 0,911 dan nilai signifikan $(0,549)>0,05$. Hal ini berarti integritas auditor tidak mampu memoderasi pengalaman kerja terhadap kualitas audit sehingga hipotesis kedua ditolak.

Berdasarkan tabel 5.17 diatas maka dapat dibuat persamaan model sebagai berikut:

$\begin{array}{ll}\mathrm{Y}= & 61.646-0.079 \mathrm{X} 1-3.557 \mathrm{X} 2+1.162 \mathrm{X} 3- \\ & 0.763 \mathrm{X} 4+0.004 \mathrm{X} 1 . \mathrm{X} 4+0.080 \mathrm{X} 2 . \mathrm{X} 4- \\ & 0.023 \mathrm{X} 3 . \mathrm{X} 4+\mathrm{e} \\ & \text { dengan } \\ \mathrm{Y} \quad & =\text { Kualitas Audit } \\ \mathrm{X} 1 \quad=\text { Tekanan anggaran waktu } \\ \mathrm{X} 2 \quad=\text { Kompleksitas tugas } \\ \mathrm{X} 3 \quad=\text { Pengalaman kerja } \\ \mathrm{X} 4 \quad=\text { Integritas kerja } \\ \mathrm{X} 1 . \mathrm{X} 4 \text { = Tekanan anggaran waktu dan integritas } \\ \quad \text { kerja } \\ \mathrm{X} 2 . \mathrm{X} 4 \text { = Kompleksitas tugas dan integritas kerja } \\ \mathrm{X} 3 . \mathrm{X} 4 \text { = Pengalaman kerja dan integritas kerja }\end{array}$

\section{Pembahasan}

\section{Pengaruh tekanan anggaran waktu terhadap kualitas audit dengan integritas sebagai pemoderasi}

Hasil penelitian ini menunjukkan bahwa integritas tidak terbukti memoderasi pengaruh tekanan anggaran waktu pada kualitas audit.
Integritas bukan variabel moderasi dalam pengaruh tekanan anggaran waktu pada kualitas audit (nilai signifikan $(0,924)>0,05)$. Meskipun demikian, kualitas audit tetap dapat dipertahankan, walaupun sebagian besar responden merasakan adanya tekanan anggaran waktu yang tinggi. Hal ini dapat disebabkan adanya tekanan ketaatan (obedience pressure) yang mewajibkan auditor untuk berkomitmen melaksanakan integritas.

Hasil penelitian ini karena tekanan anggaran waktu dalam kategori tinggi, bentuk tekanan yang muncul dari keterbatasan sumber daya berupa waktu yang dialokasikan untuk melaksanakan seluruh tugas audit yaitu tim audit merasakan anggaran waktu yang disediakan terlalu sedikit, sehingga terasa cukup berat atas beban pekerjaannya dan anggaran waktu merupakan keputusan yang mutlak dari atasan yang tidak dapat diganggu gugat, akan tetapi kualitas audit kualitas audit dalam sedang dan lebih kearah tinggi, responden setuju pada penerimaan penugasan, tim audit menetapkan sasaran, ruang lingkup, metodologi audit sehingga hasil audit memuat temuan dan simpulan hasil audit secara obyektif, serta rekomendasi yang konstruktif.

Hasil penelitian ini sesuai dengan penelitian Purnamasari (2017) bahwa bahwa variabel integritas auditor tidak mampu memoderasi pengaruh tekanan anggaran waktu terhadap kualitas audit, dikarenakan integritas auditor dalam penelitian ini masih rendah. Menurut Silaban (2009), anggaran waktu audit yang ketat dapat mengakibatkan auditor merasakan tekanan anggaran waktu dalam

pelaksanaan program audit, karena ketidakseimbangan antara anggaran waktu audit yang tersedia dan waktu yang dibutuhkan untuk penyelesaian program audit. Tekanan anggaran waktu mengakibatkan menurunnya efektifitas dan efisiensi kegiatan pengauditan. Pada program yang terstruktur, penurunan efektifitas ini semakin besar, sedangkan pada program yang tidak terstruktur, efisiensi audit akan mengalami penurunan yang signifikan.

Hal ini dapat dijelaskan bahwa kualitas audit dapat dicapai oleh auditor apabila auditor memiliki kompetensi yang baik, dimana kompetensi tersebut dilihat dari dua dimensi, 
yaitu pengetahuan dan pengalaman. Semakin tinggi independensi yang dimiliki oleh auditor, maka kualitas audit yang dihasilkan akan semakin baik. Keberadaan anggaran waktu yang ketat telah dianggap suatu hal yang lazim dan merupakan cara untuk mendorong auditor untuk bekerja lebih keras dan efisien. Kualitas audit yang dipengaruhi oleh independensi dan etika dalam melaksanakan tugas audit masih terkait dengan perilaku klien kepada auditor. Klien yang menginginkan hasil audit sesuai dengan kebutuhannya tentu akan memperlakukan auditor dengan lebih baik dimana auditor harus bersikap tegas jika dihadapkan pada situasi yang demikian.

Tekanan Anggaran Waktu merupakan kondisi dimana auditor merasa bahwa waktu pengerjaan audit yang diberikan tidak rasional dengan jumlah pekerjaan yang harus dikerjakan. Tingkat Tekanan Anggaran Waktu yang tinggi membuat auditor memiliki kecenderungan untuk melakukan Perilaku Pengurangan Kualitas Audit untuk dapat mencapai target anggaran waktu yang ditetapkan. Semakin tinggi Tekanan Anggaran Waktu yang dirasakan auditor, maka akan semakin tinggi pula kecenderungan auditor dalam melakukan Perilaku Pengurangan Kualitas Audit.

\section{Pengaruh kompleksitas tugas terhadap kualitas audit dengan integritas sebagai pemoderasi}

Berdasarkan hasil penelitian menunjukkan bahwa variabel integritas auditor mampu memoderasi pengaruh kompleksitas tugas terhadap kualitas audit. Dimana pengaruh yang ditimbulkan akan memperkuat hubungan antara kompleksitas tugas dan kualitas audit. Integritas dalam diri auditor sangat diperlukan apabila seorang auditor menginginkan kualitas audit yang baik pada saat auditor mengalami kompleksitas tugas yang tinggi. Kompleksnya suatu tugas auditor akan berpengaruh terhadap kemampuan auditor tersebut dalam mengaudit laporan keuangan instansi. Dengan adanya integritas, mengharuskan auditor untuk mengikuti prinsip objektivitas serta kehatihatian profesional sehingga kompleksitas tugas yang dihadapi auditor dapat di atasi dan menghasilkan kualitas audit yang baik.

Teori resilience Grotberg tahun 1995
(Halim, 2014) mengasumsikan bahwa setiap individu memiliki kemampuan untuk menghadapi dan mengatasi suatu tekanan pekerjaan (resilience). Pada level maju pesat (thriving), individu yang resilience mampu menghadapi dan mengatasi kondisi yang menekan dan menantang, dengan mendatangkan kemampuan baru yang membuat individu menjadi lebih baik. Salah satu karakteristiknya, yaitu memiliki pengetahuan yang memadai. Libby dan Frederick (1990) mengemukakan bahwa pengetahuan sangat penting bagi auditor. Ketika lingkungan audit berubah, auditor perlu meningkatkan pengetahuan untuk praktik terbaik yang digunakan untuk membuat pertimbangan (judgment).

Kompleksitas tugas audit didasarkan pada persepsi individu tentang kesulitan suatu tugas audit, peningkatan kompleksitas dalam suatu tugas atau sistem, akan menurunkan tingkat keberhasilan tugas itu. Terkait dengan kegiatan pengauditan, tingginya kompleksitas audit tidak menjadi penyebab auditor berperilaku disfungsional sehingga menyebabkan penurunan kualitas audit. Kompleksitas tugas merupakan tingkat kesulitan tugas dan struktur tugas yang diemban oleh auditor. Tingkat kompleksitas tersebut tergantung dari banyaknya informasi tentang tugas tersebut dan tingkat keakuratan informasi yang ada. Sikap pada setiap individu yang memiliki kemampuan kapabilitas dan daya ingat yang tinggi sehingga auditor yang mengalami kesulitan dalam melaksanakan tugas dapat peningkatka keberhasilan tugas yang berdampak juga pada peningkatan kualitas hasil audit.

Integritas auditor memerlukan kepribadian yang memiliki rasa tanggung jawab apabila hasil audit yang dilakukannya ternyata masih memerlukan perbaikan dan penyempurnaan, dan mampu memformulasikan beberapa kemungkinan jalan keluar terhadap permasalahan yang timbul. Orang yang memiliki integritas tinggi akan lebih inovatif dan produktif dibandingkan dengan orang yang memiliki integritas rendah. Dengan demikian, auditor yang berintegritas diharapkan berinovasi dan produktif dalam menyelesaikan tugas yang kompleks.

Pada penelitian ini, data profil responden menunjukkan bahwa $96 \%$ responden telah 
memiliki tingkat pendidikan Strata I/Diploma IV dan telah menerima sertifikasi dalam jenjang auditor ahli (diklat pengendali teknis, ketua tim dan ahli anggota tim). Dengan demikian, tim audit telah memiliki pengetahuan yang memadai sehingga mampu menggunakan kemahiran profesionalnya untuk mengatasi kompleksitas tugas dalam penugasan dan mempertahankan kualitas audit.

Hasil penelitian ini sesuai dengan penelitian yang dilakukan Purnamasari (2017) bahwa integritas terbukti mempunyai pengaruh kompleksitas tugas pada kualitas audit. Integritas variabel moderasi dalam pengaruh kompleksitas tugas pada kualitas audit. Kualitas audit tetap dapat dipertahankan, walaupun sebagian besar responden menyatakan setuju adanya kompleksitas tugas yang tinggi. Hal ini dapat disebabkan karena pengetahuan yang dimiliki auditor cukup memadai untuk mendukung kemahiran profesional dalam menghadapi kompleksitas tugas audit.

Hasil penelitian ini tidak sesuai dengan penelitian yang dilakukan Jamilah dkk.(2007), Zulaikha (2007), Praditaningrum dan Januarti (2012) menunjukkan bahwa kompleksitas tugas tidak berpengaruh secara signifikan pada kinerja auditor dalam pembuatan dan keakuratan judgment. Hal ini mengindikasikan bahwa auditor yang dapat memahami tugasnya, tidak mendapat kesulitan untuk menyelesaikan tugas yang dikerjakannya.

\section{Pengaruh pengalaman kerja terhadap kualitas audit dengan integritas sebagai pemoderasi}

Hasil penelitian ini menunjukkan bahwa integritas tidak terbukti memoderasi pengaruh pengalaman kerja pada kualitas audit. Integritas bukan variabel moderasi dalam pengaruh pengalaman kerja pada kualitas audit (nilai signifikan $(0,549)>0,05)$. Hal ini dapat disebabkan karena integritas tidak mendukung auditor untuk mendayagunakan pengalaman yang dimilikinya dalam penugasan, sehingga tidak memengaruhi kualitas audit.

Berdasarkan data profil responden, mayoritas responden telah memiliki pengalaman kerja 1-5 tahun. Hal ini dapat mengakibatkan pengalaman yang kurang pada bidang pengawasan sebelumnya tidak efektif untuk penugasan pada bidang pengawasan yang baru ditempati. Selain itu, penunjukkan peran dalam penugasan juga tidak mendukung auditor untuk mendayagunakan pengalaman yang dimilikinya. Sebagai contoh, seorang auditor yang telah memeroleh sertifikasi pengendali teknis, meskipun masih berada pada jenjang auditor muda, dapat diperankan sebagai pengendali teknis. Sebaliknya, seorang auditor penyelia, meskipun belum memeroleh sertifikasi ahli anggota, dapat dipertimbangkan untuk berperan sebagai ketua tim. Hal tersebut akan memunculkan pengalaman baru untuk peran yang baru diembannya.

Hasil penelitian ini sesuai dengan penelitian yang dilakukan oleh Susilo (2017), bahwa integritas tidak terbukti memperkuat pengaruh pengalaman kerja pada kualitas audit Badan Pengawasan Keuangan dan Pembangunan (BPKP). Integritas bukan variabel moderasi dalam pengaruh pengalaman kerja pada kualitas audit. Pengalaman auditor akan terus meningkat seiring dengan makin banyaknya audit yang dilakukan serta kompleksitas transaksi keuangan perusahaanyang diaudit sehingga akan menambah dan memperluas pengetahuannya di bidang akuntansi dan auditing (Christiawan, 2012).

Auditor yang berpengalaman memiliki keunggulan dalam hal mendeteksi kesalahan, memahami kesalahan secara akurat, dan mencari penyebab kesalahan. Auditor yang berpengalaman lebih banyak menemukan itemitem yang tidak umum (atypical) dibandingkan auditor yang kurang berpengalaman. Selain itu, beberapa penelitian terdahulu menunjukkan bahwa pengalaman kerja berpengaruh secara signifikan terhadap kualitas hasil audit (Sukriah dkk., 2009; Mabruri dan Winarna, 2010; Wiratama dan Budiartha, 2015). Namun, hasil penelitian Nugraheni (2009), Singgih dan Bawono (2010) menemukan bahwa pengalaman auditor pemerintah tidak terbukti berpengaruh dalam meningkatkan kualitas audit. Singgih dan Bawono (2010) menyebutkan bahwa expectation gapantara pengetahuan dan praktik yang dimiliki auditor menjadi penyebab kurang berperannya pengalaman pada kualitas audit. 


\section{Kesimpulan}

Berdasarkan hasil penelitian dan pembahasan yang telah dilakukan, maka kesimpulan yang dapat diambil adalah sebagai berikut 1) Tidak terdapat pengaruh tekanan anggaran waktu terhadap kualitas audit dengan integritas sebagai pemoderasi di Inspektorat Kabupaten Tegal 2) Terdapat pengaruh kompleksitas tugas terhadap kualitas audit dengan integritas sebagai pemoderasi di Inspektorat Kabupaten Tegal 3) Tidak terdapat pengaruh pengalaman kerja terhadap kualitas audit dengan integritas sebagai pemoderasi di Inspektorat Kabupaten Tegal

6. Saran

Penelitian ini diharapkan pihak Inspektorat Kabupaten Tegal berusaha melakukan pendidikan dan pelatihan pada auditor, audit sebaiknya dilakukan oleh auditor yang sudah cukup berpengalaman, atau dapat juga diberikan pada auditor yang belum cukup memiliki pengalaman kerja tetapi harus didampingi oleh auditor yang sudah cukup berpengalaman.

\section{DAFTAR PUSTAKA}

Agoes, Sukrisno dan Ardana, I Cenik. 2009. Etika Bisnis dan Profesi: Tantangan Membangun Manusia Seutuhnya. Jakarta: Salemba Empat.

Ayuni, Luh Winda Asri dan Suprasto, Bambang. 2015. Inteegritas Sebagai Pemoderasi Pengaruh Kompleksitas Tugas Terhadap kualitas Audit.

Cahyono, Andy D., Andy Fefta Wijaya dan Tjahjanulin Domai. 2015. Pengaruh Kompetensi, Independensi, Obyektivitas, Kompleksitas Tugas, dan Integritas Auditor terhadap Kualitas Hasil Audit. Reformasi, 5 (1).

DeZoort, F. Todd, Travis Holt dan Mark H. Taylor. 2012. A Test of The Auditor Reliability Framework Using Lenders' Judgments. Accounting, Organizations and Society, 37: 519-533.

Engko, Cecilia dan Gudono. 2007. Pengaruh Kompleksitas Tugas dan Locus of Control terhadap Hubungan antara
Gaya Kepemimpinan dan Kepuasan Kerja Auditor. Simposium Nasional Akuntansi X.

Herrbach, Olivier. 2001. Audit Quality, Auditor Behaviour and The Psychological Contract. European Accounting Review, 10 (4): 787-802.

Karapetrovic, S. dan Willborn, W. 2010.Quality Assurance and Effectiveness of Audit Systems.International Journal of Quality\& Reliability Management, 17 (6): 679-703.

Lowensohn, S., Laurence E. Johnson, dan Randal J. Elder. 2005. Auditor Specialization and Perceived Audit Quality, Auditee Satisfaction and Audit Fees in The Local Government Audit Market. Paper.

Nugraheni, Oktina. 2019. "Pengaruh FaktorFaktor Personal Auditor Internal terhadap Kualitas Audit" (tesis).

Pemerintah Kabupaten Tegal, 2016.Peraturan Bupati Tegal Nomor 70 Tahun 2016 tentang Kedudukan, Susunan Organisasi, Tugas Dan Fungsi Serta Tata Kerja Inspektorat Kabupaten Tegal Penjabaran Tugas Pokok Dan Fungsi, Serta Tata Kerja Inspektur, Sekretaris, Inspektur Pembantu Wilayah, Kepala Sub Bagian Dan Kelompok Jabatan Fungsional Di Lingkungan Pemerintah Kabupaten Tegal.

Pemerintah Republik Indonesia. 2008. Peraturan Pemerintah Republik Indonesia Nomor 60 Tahun 2008 tentang Sistem Pengendalian Intern Pemerintah.

Prabowo, Tri Jatmiko Wahyu., Philomena Leung dan James Guthrie. 2013. New Public Financial Management in Indonesia (1999-2012): Confusion in Implementation. The Seventh Asia Pacific Interdisciplinary Research in Accounting Conference.

Praditaningrum, Anugerah S. dan Januarti, Indira. 2012. Analisis faktor-faktor yang berpengaruh terhadap Audit Judgment. Simposium Nasional Akuntansi XV. 
Prasita, A. dan Adi, Priyo H. 2007.Pengaruh Kompleksitas Audit dan Tekanan Anggaran Waktu terhadap Kualitas Audit dengan Moderasi Pemahaman terhadap Sistem Informasi.Jurnal Ekonomi dan Bisnis Fakultas Ekonomi Universitas Kristen Satya Wacana, September.

Rai, I Gusti Agung. 2008. Audit Kinerja pada Sektor Publik. Jakarta: Salemba Empat.

Ramsay, R. J. 1994. Senior/Manager Differences in Audit Workpaper Review Performance.Journal of Accounting Research, 32 (1): 127-135.

Singgih, Elisha M. dan Bawono, Icuk R. 2010. Pengaruh Independensi, Pengalaman, Due Professional Care dan Akuntabilitas terhadap Kualitas Audit. Simposium Nasional Akuntansi XIII.

Sososutikno, Christina. 2003. Hubungan Tekanan Anggaran Waktu dengan Perilaku Disfungsional Serta Pengaruhnya Terhadap Kualitas Audit.Simposium Nasional Akuntansi VI.

Sukriah, Ika., Akram dan Biana Adha Inapty. 2009. Pengaruh Pengalaman Kerja, Independensi, Obyektifitas, Integritas dan Kompetensi Terhadap Kualitas Hasil Pemeriksaan. Simposium Nasional Akuntansi XII.

Tan, H-T., and K. Jamal. 2001. Do Auditors

Objectively Evaluate Their Subordinates' Work? The Accounting Review, 76 (1): 99-110.

Tubbs, R. M. 1992. The Effect of Experience on The Auditor's Organization and Amount of Knowledge. The Accounting Review. 67 (4): 783-801.

Ulum MD., Ihyaul. 2009. Audit Sektor Publik: Suatu Pengantar. Ed. 1, Cet. 1. Jakarta: PT Bumi Aksara.

Waggoner, J. B. dan James D. Cashell. 1991. The Impact of Time Pressure on Auditor's Performance. Ohio CPA Journal. 50.

Widiarta. 2013. Pengaruh Gender, Umur dan Kompleksitas Tugas Auditor pada Kualitas Audit Kantor Akuntan Publik di Bali. E-Jurnal Akuntansi

Universitas Udayana, 3 (1): 109-118.

Willet dan Page, 1996

Willett, Caroline dan Page, Michael. 1996. A Survey of Time Budget Pressure and Irregular Auditing Practices among Newly Qualified UK Chartered Accountants. British Accounting Review 28: 101-120.

Wiratama, William J. dan Budiartha, Ketut. 2015. Pengaruh Independensi, Pengalaman Kerja, Due Professional Care dan Akuntabilitas terhadap Kualitas Audit. E-jurnal Akuntansi Universitas Udayana, 10 (1): 91-106.

Wood, Robert E. 1986. Task Complexity: Definition of The Construct. Organizational Behavior and Human Decision Processes, 37: 60-82.

Zulaikha. 2006. Pengaruh Interaksi Gender, Kompleksitas Tugas dan Pengalaman Auditor terhadap Audit Judgment. Simposium Nasional Akuntansi IX. 